\title{
Changes in dry matter, protein percentage and organic matter of soybean-oat and groundnut-oat intercropping in different growth stages in Jilin province, China
}

\author{
Yang YONG $^{1 *}$, Yue-gao $\mathrm{HU}^{2}$, Mohamad Hesam SHAHRAJABIAN ${ }^{2}$,Chang-zhong REN ${ }^{3}$, Lai-chun GUO ${ }^{3}$, Chun- \\ long $\mathrm{WANG}^{3}$, Zhao-hai $\mathrm{ZENG}^{2}$
}

Received March 30, 2017; accepted January 26, 2018.

Delo je prispelo 30. marca 2017, sprejeto 26. januarja 2018.

\begin{abstract}
One of the most important and sustainable cropping practice is intercropping. The study was conducted under field conditions in the arid Horqine sandy land in Baicheng District, Jilin Province, Northern China in 2011. A randomized complete block design with four replications was used. Treatments comprised different mono cropping and intercropping patterns, TO: sole cropping of oat, TOS-O: oat in the intercropping of oat and soybean, TOG-O: oat in the intercropping of oat and groundnut, TS: sole cropping of soybean, TOS-S: soybean in intercropping of oat and soybean, TG: sole cropping of groundnut, TOG-G: groundnut in the intercropping of oat and groundnut. In mono-cropping systems, oat mono-cropping obtained the highest dry matter and nitrogen accumulation in all growth stages. The maximum protein percentage in all stages except for ripening stage, were for groundnut monocropping. Although, the maximum organic matter in ripening stage was achieved in mono-cropping of soybean, the highest one in other stages was related to groundnut mono-cropping. In intercropping patterns, oat in oat-groundnut obtained the highest dry matter in all stages. The highest value of protein percentage and organic matter in heading stage, grain filling stage, and grain dough stage was achieved in groundnut in oatgroundnut intercropping. Furthermore, the maximum value of protein percentage and organic matter in booting stage and ripening stage was related to soybean in oat-soybean intercropping. The results of this study clearly indicate that intercropping oat and groundnut affects the growth rate of the individual species in mixtures as well as the dry matter yield and nitrogen accumulation. This information can help in the adaptation of oat- intercrops for increased forage production in new cropping systems.
\end{abstract}

Key words: protein percentage; organic matter; soybean; groundnut; oat; intercropping
IZVLEČEK

\author{
SPREMEMBA SUŠINE, ORGANSKE MASE IN \\ VSEBNOSTI BELJAKOVIN V VMESNIH POSEVKIH \\ SOJE, OVSA IN ARAŠIDOV V RAZLIČNIH FAZAH \\ RAZVOJA IN RASTI V PROVINCI JILAN, KITAJSKA
}

Eden najpomembnejših ukrepov za trajnostni način pridelave poljščin je vmesna setev. V raziskavi je bil izveden popolni naključni poljski poskus s štirimi ponovitvami na suhih peščenih tleh v Horkinu, območje Baicheng, v provinci Jilin v severni Kitajski, leta 2011. Obravnavanja so obsegala različne načine setve $\mathrm{v}$ čistem posevku in $\mathrm{v}$ vmesnem posevku, in sicer: čisti posevek ovsa (TO); setev ovsa v vmesnem posevku s sojo (TOS$\mathrm{O}$ ); setev ovsa $\mathrm{v}$ vmesnem posevku $\mathrm{z}$ arašidi (TOG-O); čisti posevek soje (TS); setev soje v vmesnem posevku z ovsom (TOS$\mathrm{S}$ ); čisti posevek arašidov (TG); arašidi v vmesnem posevku z ovsom (TOG-G). Pri setvi čistih posevkov je imel čisti posevek ovsa največjo vsebnost suhe mase in dušika $v$ vseh razvojnih fazah. Največji odstotek beljakovin je bil v vseh fazah razvoja, $z$ izjemo faze zorjenja, $\mathrm{v}$ čistih posevkih arašidov. Največja vsebnost organske mase je bila $\mathrm{v}$ čistih posevkih soje dosežena $\mathrm{v}$ fazi zorenja, $\mathrm{v}$ drugih razvojnih fazah pa $\mathrm{v}$ čistih posevkih arašidov. $\mathrm{V}$ vmesnih posevkih je imel posevek ovsa $\mathrm{Z}$ arašidi največjo vsebnost suhe mase $\mathrm{v}$ vseh fazah rasti in razvoja. Največji odstotek beljakovin in vsebnost organske snovi $v$ fazah latenja, polnjenja zrnja in fazi voščene zrelosti zrnja sta bila dosežena $\mathrm{v}$ sistemu setve arašidov $\mathrm{z}$ medsetvijo arašidov $\mathrm{z}$ ovsom. Največji vsebnosti beljakovin in organske mase $v$ fazah kolenčenja in zorenja sta bili doseženi $\mathrm{v}$ vmesnih posevkih soje $\mathrm{z}$ ovsom. Rezultati raziskave jasno nakazujejo, da setev ovsa $\mathrm{v}$ vmesnem posevku $\mathrm{z}$ arašidi vpliva na rast posameznih poljščin $\mathrm{v}$ mešanicah kot tudi na pridelek suhe mase in odvzem dušika. Pridobljene izkušnje lahko pomagajo prilagoditvam vmesnih posevkov z ovsom za povečanje pridelave krme v novih načinih pridelave.

Ključne besede: vsebnost beljakovin; sušina; organska masa; soja; arašidi; oves; vmesna setev

\footnotetext{
1 Hami melon research center, Xinjiang Academy of agricultural sciences; *e-mail:yangyongsj@gmail.com, yangyongsj062@163.com

2 College of Agronomy and Biotechnology, China Agricultural University, Beijing 100193, China

3 Baicheng Academy of Agricultural Sciences, Baicheng 137000, China
} 


\section{INTRODUCTION}

Intercropping, the mixed growth of two or more crops, is practiced in more than 28 million hectares of areas sown annually in China. Multiple-cropping systems in China, including intercropping and related practices, have contributed to increased crop productivity due to a more effective utilization of resources compared to monoculture crops (Karimuna et al., 2012).Cereallegume intercropping system was experimented by many researchers in all over the world (Carr et al., 2004; Lithourgidis et al., 2006; Lauk and Lauk, 2008; Li et al., 2009; Soleymani et al., 2011; Soleymani et al., 2012). The benefits of oat intercropping with other crops are also reported by many researchers (Malezieus et al., 2009; Naumann et al., 2010; Gong et al., 2011; Han et al., 2012). Researchers also reported the improvement of peanut production in intercropping system (Justino and Sodek, 2013). The inclusion of legumes in crop rotations and intercrops can provide increased proteinrich yields and a more sustainable source of nitrogen, while on the other side it saves cost by reducing the requirement for mineral nitrogen application (Crew and Peoples, 2004). On the one hand, monocultures of legumes and cereals do not provide satisfactory results for forage production (Soleymani et al., 2011; Soleymaniand Shahrajabian., 2012). On the other hand, small grain cereals provide high yield in terms of dry mass but they produce forage with low protein content (Lauk and Lauk, 2008). Other benefits of mixtures include greater uptake of water and nutrients, enhanced weed suppression, and increased soil conservation ( $\mathrm{Li}$ et al., 2009). These systems also protect soil against erosion, improve the use of limited resources, improve forage quality, increase stability of yield and provide higher returns (Javanmard et al., 2009; Lee and Yoon, 2013). Intercropping of legumes with non-legumes results in production of more dry matter and an increase in protein content of the resulting crop, with minimum $\mathrm{N}$ fertilizer input (Ijoyah and Fanen, 2012).Caballero and Goicoechea (1986) reported that the most suitable cereal for mixtures with legume is oat (Avena sativa $\mathrm{L}$.). Soybean (Glycine max (L.) Merrill), which is one of the major legume crops produced worldwide (Garrett et al., 2013; Jing and Chin, 2013; Mazza et al., 2013), is commercially used for its edible oil, proteins, health functional ingredients, and fermented food (Jensen, 1996; Sharma et al., 2013). Materials left after evaporation is the dry matter, while loss in weight upon ignition at certain defined temperature is the organic matter content. This research had three aims. The first was to study the organic matter production in monocropping and intercropping patterns. The second aim was to evaluate nitrogen and protein percentage for each treatment. The third aim was to study changes of dry matter in different stages of oat intercropped by soybean and groundnut.

\section{MATERIALS AND METHODS}

The study was conducted under field conditions in the arid Horqine sandy land in Baicheng District $\left(44^{\circ} 14^{\prime}\right.$ $46^{\circ} 18^{\prime} \mathrm{N}, 121^{\circ} 38^{\prime}-124^{\circ} 22^{\prime} \mathrm{E}$ ), Jilin Province, Northern China in 2011. A randomized complete block design with four replications was used. Treatments comprised different mono cropping and intercropping patterns, TO: sole cropping of oat (Avena sativa 'Baiyan2'), TOS-O: oat in the intercropping of oat and soybean (Glycine max 'Zao Shu96136'), TOG-O: oat in the intercropping of oat and groundnut (Arachis hypogaea 'Baiyuanhual'), TS: sole cropping of soybean, TOS-S: soybean in intercropping of oat and soybean, TG: sole cropping of groundnut, TOG-G: groundnut in the intercropping of oat and groundnut. No nitrogen fertilizer was used in this research. $55 \mathrm{~kg} \mathrm{ha}^{-1} \mathrm{P}_{2} \mathrm{O}_{5}, 45$ $\mathrm{kg} \mathrm{ha}^{-1} \mathrm{~K}_{2} \mathrm{O}, 4.5 \mathrm{~kg} \mathrm{ha}^{-1} \mathrm{FeSO}_{4}, 1 \mathrm{~kg} \mathrm{ha}^{-1} \mathrm{H}_{3} \mathrm{BO}_{3}, 1.5 \mathrm{~kg}$ $\mathrm{ha}^{-1} \mathrm{Na}_{2} \mathrm{MOO}_{4} \cdot 2 \quad \mathrm{H}_{2} \mathrm{O}$ were applied as basal fertilizers. An automatic weather station was installed in the experimental field to record daily air temperature and rainfall during growing period. Available nitrogen, phosphorus and potassium at the mentioned depth were $66.6 \mathrm{mg} \mathrm{kg}{ }^{-1}, 14.2 \mathrm{mg} \mathrm{kg}^{-1}$ and $68.2 \mathrm{mg} \mathrm{kg}^{-1}$, respectively. Soil $\mathrm{pH}$ was 7.2. No additional fertilizers were used during growth stages. Soybean and groundnut seeds were mixed with rhizobia before plantation. The soybean density in monoculture was $10 \times 60 \mathrm{~cm}$ with 1 seedling in each hole, which is equivalent to 167 thousand plants per ha. The groundnut density in monoculture was $20 \times 60 \mathrm{~cm}$ with two seedlings in each hole, equivalent to 167 thousand plants per ha. The seed quantity of oat in monoculture was $200 \mathrm{~kg} \mathrm{ha}^{-1}$. In soybean and groundnut monoculture, the distance between two rows was $60 \mathrm{~cm}$, and the distance between seedlings on the row was $10 \mathrm{~cm}$ and $20 \mathrm{~cm}$, respectively. Oat seed rate per row for both monoculture and intercropping patterns were the same. In intercropping patterns, the distance between both groundnut and soybean row with oat rows were $20 \mathrm{~cm}$. The ration of both soybean and groundnut intercropping with oat was 2: 2. All seeds were sown by skillful workers on May 17th; furthermore, oat and legumes were harvested on $12^{\text {th }}$ August and $7^{\text {th }}$ September. Intercultural operations such as weeding and plant protection were done when required to ensure and 
maintain the normal growth of crop. The amount of nitrogen was determined by Kjeldahl analysis from dry and ground samples, and nitrogen was multiplied by 6.25 to determine protein content. (Pregl, 1945). Dry matter was determined by drying samples for $15 \mathrm{~h}$ at $105^{\circ} \mathrm{C}$; dry matter was expressed as a percentage of the sample at the time of the analysis. Organic matter was determined by ashing for at least $4 \mathrm{~h}$ at $500{ }^{\circ} \mathrm{C}$. All data were statistically treated using Analysis of variance (ANOVA) for randomized complete block design and the means were compared by Duncan's multiple range method using SAS software program $(P \leq 0.05)$.

\section{RESULTS AND DISCUSSION}

\subsection{Booting stage}

There was no significant difference in nitrogen concentration among cropping patterns. Oat dry matter in booting stage in oat-soybean intercropping was higher than oat yield in oat-groundnut intercropping and other treatments, which had significant differences with other treatments. The maximum nitrogen accumulation in booting stage was also obtained for oat in intercropping of oat and soybean (Table 1). Protein percentage of soybean in oat-soybean intercropping obtained the maximum value $(20.95 \%)$. The highest value of organic matter was obtained for soybean in oatsoybean intercropping, followed by ground nut in oatgroundnut intercropping and oat in oat-soybean intercropping. Moreover, there was not any significant difference in organic matter of oat in both oat-groundnut and oat-soybean intercropping. In mono-cropping, the maximum organic matter in booting stage was achieved for groundnut mono-cropping $(26.82 \%)$ (Table 3). Using cereals intercropped with legumes improves the value of farming systems, moreover, the selection of appropriate intercropping system remains the best approach (Soleymani and Shahrajabian, 2012).

\subsection{Heading stage}

In solo-cropping patterns, the highest dry matter in heading stage was obtained for oat mono-cropping, followed by soybean and groundnut mono-cropping. On the one hand, there was no significant difference in dry matter and nitrogen accumulation between dry matter of oat in oat-groundnut and oat-soybean intercropping. In the other hand, oat in oat-groundnut obtained the highest value of dry matter and nitrogen accumulation (Table 1). Mono-cropping of groundnut obtained the maximum value of protein percentage $(15.79 \%)$ and organic matter $(21.39 \%)$. Groundnut in oat-groundnut intercropping had obtained the maximum value of protein percentage in heading stage, which had significant differences with oat in both oat-soybean and oat-groundnut intercropping; however, its difference with soybean in oat-soybean intercropping was not significant. Crude protein concentration of forage is one the most important criteria for forage quality evaluation (Dordas and Lithourgidis, 2011). Organic matter value of groundnut in oat-groundnut intercropping $(21.39 \%)$ in heading stage was significantly higher than in other intercropping treatments. Furthermore, the difference in organic matter of oat in both oat-soybean and oatgroundnut intercropping was not meaningful (Table 3).

\subsection{Grain filling stage}

In mono-cropping patterns, the highest value of dry matter was obtained for oat, followed by soybean and groundnut. In intercropping patterns, the highest and the lowest dry matter production was related to oat yield in oat-groundnut intercropping, and groundnut in oatgroundnut intercropping. Some other researchers also stated that in intercropping system of cereal with a legume, forage yield is much higher than that of the legume sole crop and forage quality is higher than that of the sole cereal crop (Mariotti et al., 2009; Dordas et al., 2012).The maximum nitrogen accumulation in grain filling stage was achieved in oat mono-cropping, which had significant differences with groundnut and soybean mono-cropping. Oat nitrogen accumulation in oatgroundnut intercropping, which had no meaningful difference with nitrogen accumulation of oat in oatsoybean, obtained the highest value of it (Table 1). The maximum value of protein percentage $(16.55 \%)$ and organic matter in grain filling stage $(22.57 \%)$ was related to groundnut mono-cropping. Protein percentage for groundnut in oat-groundnut intercropping was higher than those of other treatments. There were significant differences between groundnut in oatgroundnut intercropping and other intercropping patterns in the term of protein percentage. Indeed, there was no significant difference in organic matter for oat in oat-groundnut intercropping and oat in oat-soybean system (Table 3).

\subsection{Grain dough stage}

The highest production of dry matter and nitrogen accumulation in grain dough stage was obtained for oat mono-cropping. The highest amount of dry matter in grain dough stage was achieved in oat in oat-groundnut intercropping in comparison with those of other intercropping systems; moreover, its differences with other treatments were significant. Oat nitrogen accumulation of oat in oat-groundnut intercropping obtained the maximum value, which had meaningful differences with other treatments. In contrast, nitrogen accumulation for groundnut in oat-groundnut 
intercropping, which obtained the minimum value, had no significant difference with the one for soybean in oat-soybean intercropping (Table 2). Groundnut monocropping obtained both the maximum protein percentage $(12.69 \%)$, and organic matter $(17.26 \%)$, followed by soybean mono-cropping and oat monocropping, respectively. Among intercropping patterns, the maximum protein percentage and organic matter production was achieved in groundnut in oat-groundnut intercropping, which had no significant difference with the value of soybean in oat-soybean intercropping. Indeed, differences between oat in oat-groundnut and oat-soybean intercropping were not significant (Table 3). Ghanbari-Bonjar and Lee (2003) and Arshad and Ranamukhaarachchi (2012) concluded that intercropping had greater total output for protein content compared to sole cropped of crops.

\subsection{Ripening stage}

In solo-cropping, the highest dry matter in grain filling stage was related to oat mono-cropping, followed by mono-cropping of soybean and groundnut monocropping. On the one side, higher values of nitrogen accumulation were related to oat in oat-groundnut intercropping than those of other intercropping treatments. On the other side, the difference in oat yield in oat-groundnut and oat-soybean was not meaningful (Table 2). The maximum protein percentage in ripening stage was achieved in soybean mono-cropping followed by mono-cropping of groundnut and solo-cropping of oat, respectively. In intercropping treatments, the maximum and the minimum protein percentage was related to soybean in oat-soybean intercropping $(13.35 \%)$, and in oat in oat-groundnut intercropping $(8.95 \%)$, respectively. But, Li et al. (2009) reported that there were no significant differences in protein content between intercropping and sole cropping. Legumecereal intercrops have produced higher seed and protein yields than pure cereal crops (Jensen, 1996; HauggaardNilsen et al., 2001; Lauk and Lauk, 2005). The highest and the lowest amount of organic matter were related to soybean mono-cropping $(17.36 \%)$, and oat monocropping $(11.02 \%)$, respectively. Soybean in oatsoybean intercropping obtained the maximum organic matter in ripening stage $(18.18 \%)$, which had significant differences with oat in oat-groundnut and oat-soybean intercropping. However, it had no meaningful difference with groundnut in oat-groundnut intercropping (Table 3).

Table 1: Mean comparison for nitrogen concentration $\left(\mathrm{g} \mathrm{g}^{-1}\right.$ dry matter), dry matter $\left(\mathrm{g} \mathrm{m}^{-2}\right)$ and nitrogen accumulation $\left(\mathrm{g} \mathrm{m}^{-2}\right)$ in booting stage, heading stage and grain filling stage under different cropping patterns

\begin{tabular}{|c|c|c|c|c|c|c|c|c|c|}
\hline & Booting stage & $\begin{array}{l}\text { Booting } \\
\text { stage }\end{array}$ & $\begin{array}{l}\text { Booting } \\
\text { stage }\end{array}$ & $\begin{array}{l}\text { Heading } \\
\text { stage }\end{array}$ & $\begin{array}{l}\text { Heading } \\
\text { stage }\end{array}$ & $\begin{array}{l}\text { Heading } \\
\text { stage }\end{array}$ & $\begin{array}{l}\text { Grain filling } \\
\text { stage }\end{array}$ & $\begin{array}{l}\text { Grain } \\
\text { filling } \\
\text { stage }\end{array}$ & $\begin{array}{l}\text { Grain filling } \\
\text { stage }\end{array}$ \\
\hline Treatment & $\begin{array}{l}\text { Nitrogen } \\
\text { concentration } \\
\text { in booting } \\
\text { stage }\end{array}$ & $\begin{array}{l}\text { Dry } \\
\text { matter } \\
\text { in } \\
\text { booting } \\
\text { stage }\end{array}$ & $\begin{array}{c}\text { Nitrogen } \\
\text { accumulation } \\
\text { in booting } \\
\text { stage }\end{array}$ & $\begin{array}{c}\text { Nitrogen } \\
\text { concentration } \\
\text { in heading } \\
\text { stage }\end{array}$ & $\begin{array}{l}\text { Dry } \\
\text { matter } \\
\text { in } \\
\text { heading } \\
\text { stage }\end{array}$ & $\begin{array}{c}\text { Nitrogen } \\
\text { accumulation } \\
\text { in heading } \\
\text { stage }\end{array}$ & $\begin{array}{c}\text { Nitrogen } \\
\text { concentration } \\
\text { in grain } \\
\text { filling stage }\end{array}$ & $\begin{array}{c}\text { Dry } \\
\text { matter } \\
\text { in } \\
\text { grain } \\
\text { filling } \\
\text { stage }\end{array}$ & $\begin{array}{c}\text { Nitrogen } \\
\text { accumulation } \\
\text { in grain } \\
\text { filling stage }\end{array}$ \\
\hline TO & $0.017 \mathrm{a}$ & $73.53 c$ & $1.283 b$ & $0.011 \mathrm{a}$ & $149.7 b$ & $1.710 \mathrm{~b}$ & $0.012 \mathrm{a}$ & $205.7 b$ & $2.703 b$ \\
\hline TOG-O & $0.022 \mathrm{a}$ & $99.83 b$ & $1.273 \mathrm{a}$ & $0.013 \mathrm{a}$ & $232.2 \mathrm{a}$ & $3.327 \mathrm{a}$ & $0.013 \mathrm{a}$ & $312.9 \mathrm{a}$ & $4.251 \mathrm{a}$ \\
\hline TOS-O & $0.022 \mathrm{a}$ & $107.8 \mathrm{a}$ & $2.443 \mathrm{a}$ & $0.014 \mathrm{a}$ & $209.5 a$ & $3.103 \mathrm{a}$ & $0.013 \mathrm{a}$ & $284.6 \mathrm{a}$ & $3.913 \mathrm{a}$ \\
\hline TG & $0.031 \mathrm{a}$ & $2.400 \mathrm{~d}$ & $0.076 \mathrm{c}$ & $0.024 \mathrm{a}$ & $6.233 c$ & $0.156 \mathrm{c}$ & $0.026 \mathrm{a}$ & $11.27 \mathrm{c}$ & $0.296 \mathrm{c}$ \\
\hline TOG-G & $0.031 \mathrm{a}$ & $1.833 \mathrm{~d}$ & $0.053 \mathrm{c}$ & $0.024 \mathrm{a}$ & $6.400 \mathrm{c}$ & $0.163 \mathrm{c}$ & $0.024 \mathrm{a}$ & $10.53 c$ & $0.263 \mathrm{c}$ \\
\hline TS & $0.028 \mathrm{a}$ & $7.100 \mathrm{~d}$ & $0.200 \mathrm{c}$ & $0.022 \mathrm{a}$ & $10.07 \mathrm{c}$ & $0.233 \mathrm{c}$ & $0.023 a$ & $22.60 \mathrm{c}$ & $0.543 c$ \\
\hline TOS-s & $0.033 \mathrm{a}$ & $4.300 \mathrm{~d}$ & $0.143 \mathrm{c}$ & $0.022 \mathrm{a}$ & $8.133 c$ & $0.183 \mathrm{c}$ & $0.020 \mathrm{a}$ & $19.53 c$ & $0.406 \mathrm{c}$ \\
\hline
\end{tabular}

Mean with the same letter in each column are not significantly different at 5 percent probability level. 
Table 2: Mean comparison for nitrogen concentration ( $\mathrm{g} \mathrm{g}^{-1}$ dry matter), dry matter $\left(\mathrm{g} \mathrm{m}^{-2}\right)$ and nitrogen accumulation $\left(\mathrm{g} \mathrm{m}^{-2}\right)$ in grain dough stage and ripening stage under different cropping patterns

\begin{tabular}{ccccccc}
\hline & $\begin{array}{c}\text { Grain dough } \\
\text { stage }\end{array}$ & $\begin{array}{c}\text { Grain dough } \\
\text { stage }\end{array}$ & $\begin{array}{c}\text { Grain dough } \\
\text { stage }\end{array}$ & Ripening stage & Ripening stage & Ripening stage \\
\hline Treatment & $\begin{array}{c}\text { Nitrogen } \\
\text { concentration }\end{array}$ & Dry matter & $\begin{array}{c}\text { Nitrogen } \\
\text { accumulation }\end{array}$ & $\begin{array}{c}\text { Nitrogen } \\
\text { concentration }\end{array}$ & $\begin{array}{c}\text { Dry matter } \\
\text { accumulation }\end{array}$ \\
\hline TO & $0.012 \mathrm{a}$ & $292.5 \mathrm{~b}$ & $3.610 \mathrm{~b}$ & $0.012 \mathrm{a}$ & $246.3 \mathrm{c}$ & $3.187 \mathrm{c}$ \\
TOG-O & $0.014 \mathrm{a}$ & $333.8 \mathrm{a}$ & $5.003 \mathrm{a}$ & $0.014 \mathrm{a}$ & $345.3 \mathrm{a}$ & $4.953 \mathrm{a}$ \\
TOS-O & $0.013 \mathrm{a}$ & $292.9 \mathrm{~b}$ & $3.880 \mathrm{~b}$ & $0.014 \mathrm{a}$ & $303.7 \mathrm{~b}$ & $4.370 \mathrm{~b}$ \\
TG & $0.019 \mathrm{a}$ & $26.17 \mathrm{c}$ & $0.530 \mathrm{c}$ & $0.013 \mathrm{a}$ & $30.10 \mathrm{~d}$ & $0.430 \mathrm{e}$ \\
TOG-G & $0.020 \mathrm{a}$ & $16.73 \mathrm{c}$ & $0.350 \mathrm{c}$ & $0.017 \mathrm{a}$ & $19.37 \mathrm{~d}$ & $0.346 \mathrm{e}$ \\
TS & $0.017 \mathrm{a}$ & $37.30 \mathrm{c}$ & $0.660 \mathrm{c}$ & $0.019 \mathrm{a}$ & $43.13 \mathrm{~d}$ & $0.880 \mathrm{~d}$ \\
TOS-S & $0.018 \mathrm{a}$ & $27.63 \mathrm{c}$ & $0.520 \mathrm{c}$ & $0.021 \mathrm{a}$ & $44.50 \mathrm{~d}$ & $0.950 \mathrm{~d}$ \\
\hline
\end{tabular}

Mean with the same letter in each column are not significantly different at 5 percent probability level.

Table 3: Mean comparison for protein percentage (\%) and organic matter (\%) under different cropping patterns

\begin{tabular}{|c|c|c|c|c|c|c|c|c|c|c|}
\hline Treatment & $\begin{array}{c}\text { Protein } \\
\text { percentage } \\
\text { in booting } \\
\text { stage }\end{array}$ & $\begin{array}{l}\text { Organic } \\
\text { matter } \\
\text { in } \\
\text { booting } \\
\text { stage }\end{array}$ & $\begin{array}{c}\text { Protein } \\
\text { percentage } \\
\text { in heading } \\
\text { stage }\end{array}$ & $\begin{array}{c}\text { Organic } \\
\text { matter in } \\
\text { heading } \\
\text { stage }\end{array}$ & $\begin{array}{c}\text { Protein } \\
\text { percentage } \\
\text { in grain } \\
\text { filling } \\
\text { stage }\end{array}$ & $\begin{array}{l}\text { Organic } \\
\text { matter } \\
\text { in grain } \\
\text { filling } \\
\text { stage }\end{array}$ & $\begin{array}{c}\text { Protein } \\
\text { percentage } \\
\text { in grain } \\
\text { dough } \\
\text { stage }\end{array}$ & $\begin{array}{c}\text { Organic } \\
\text { matter } \\
\text { in grain } \\
\text { dough } \\
\text { stage }\end{array}$ & $\begin{array}{c}\text { Protein } \\
\text { percentage } \\
\text { in } \\
\text { ripening } \\
\text { stage }\end{array}$ & $\begin{array}{c}\text { Organic } \\
\text { matter } \\
\text { in } \\
\text { ripening } \\
\text { stage }\end{array}$ \\
\hline TO & & $14.87 \mathrm{~b}$ & & & $8.247 \mathrm{c}$ & $11.22 \mathrm{c}$ & $7.75 \mathrm{c}$ & $10.52 b$ & $8.103 c$ & $11.02 \mathrm{c}$ \\
\hline TOG-O & $14.09 \mathrm{~b}$ & $19.16 \mathrm{~b}$ & $8.943 b c$ & $12.160 \mathrm{bc}$ & $8.500 \mathrm{c}$ & $11.57 \mathrm{c}$ & $9.37 \mathrm{bc}$ & $12.03 \mathrm{~b}$ & $8.950 \mathrm{bc}$ & $12.17 \mathrm{bc}$ \\
\hline TOS-O & $16.15 b$ & $19.24 b$ & $9.280 \mathrm{~b}$ & $12.620 b c$ & $8.597 \mathrm{c}$ & $11.69 \mathrm{c}$ & $8.34 \mathrm{c}$ & $11.35 \mathrm{~b}$ & $8.993 b c$ & $12.24 b c$ \\
\hline TG & $19.72 \mathrm{a}$ & $26.82 \mathrm{a}$ & $15.790 \mathrm{a}$ & $21.470 \mathrm{c}$ & $16.55 \mathrm{a}$ & $22.57 \mathrm{a}$ & $12.69 \mathrm{a}$ & $17.26 \mathrm{a}$ & $8.907 b c$ & $12.11 b c$ \\
\hline TOG-G & $19.65 a$ & $26.72 \mathrm{a}$ & $15.720 \mathrm{a}$ & $21.390 \mathrm{c}$ & $15.73 a$ & $21.40 \mathrm{a}$ & $13.13 \mathrm{a}$ & $17.86 \mathrm{a}$ & $11.24 \mathrm{ab}$ & $15.28 \mathrm{ab}$ \\
\hline TS & $17.89 \mathrm{a}$ & $24.33 \mathrm{a}$ & $14.490 \mathrm{a}$ & $19.170 \mathrm{a}$ & $14.90 \mathrm{ab}$ & $20.26 \mathrm{ab}$ & $11.21 \mathrm{ab}$ & $15.25 \mathrm{a}$ & $12.76 \mathrm{a}$ & $17.36 \mathrm{a}$ \\
\hline TOS-S & $20.95 a$ & $28.49 \mathrm{a}$ & $14.410 \mathrm{a}$ & $19.60 \mathrm{a}$ & $13.12 \mathrm{~b}$ & $17.85 \mathrm{~b}$ & $11.82 \mathrm{a}$ & $16.08 \mathrm{a}$ & $13.36 \mathrm{a}$ & $18.18 \mathrm{a}$ \\
\hline
\end{tabular}

Mean with the same letter in each column are not significantly different at 5 percent probability level.

\section{CONCLUSION}

Using cereals intercropped with legumes improves the value of farming systems, moreover, the selection of appropriate intercropping system remains the best approach. Moreover, mixing species in cropping systems may lead to a range of benefits that are expressed on various space and time scales, from a short-term increase in crop yield and quality, to longterm increase in crop yield and quality, to long-term agro-ecosystem sustainability, up to societal and ecological benefits. The results of this study clearly indicate that intercropping oat and groundnut affects the growth rate of the individual species in mixtures as well as the dry matter yield and nitrogen accumulation. This information can help in the adaptation of oat-intercrops for increased forage production in new cropping systems.

\section{REFERENCES}

Arshad, M., Ranamukhaarachchi, S. L. (2012).Effects of legume type, planting pattern and time of establishment on growth and yield of sweet sorghum-legume intercropping. Australian Journal of Crop Science, 6(8), 1265-1274.

Caballero, R., Goicoechea, E.L. (1986). Utilization of winter cereals as companion crops for common vetch and hairy vetch. In: Proceedings of the $11^{\text {th }}$ General Meeting of the European Grass. Fed. Pp. 379-384.
Carr, P.M., Horsley, R.D., Poland, W.W. (2004).Barley, oat and cereal-pea mixtures as dryland forages in the Northern Great Plains.Agronomy Journal, 96, 677-684. doi:10.2134/agronj2004.0677

Crews, T. E., and Peoples, M. B. (2004). Legume versus fertilizer sources of nitrogen: ecological tradeoffs and human needs. Agriculture, Ecosystems \& Environment, 102,279-297. doi:10.1016/j.agee.2003.09.018

Dordas, C.A., Lithourgidis, A.S. (2011). Growth, yield and nitrogen performance of faba bean intercrops 
with oat and triticale at varying seeding ratios. Grass and Forage Science, 66, 569-577. doi:10.1111/j.1365-2494.2011.00814.X

Dordas, C.A., Vlachostergios, D.N., Lithourgidis, A.S. (2012).Growth dynamics and agronomic-economic benefits of pea-oat and pea-barley intercrops. Crop and Pasture Science, 63(1), 45-52. doi:10.1071/CP11181

Garrett, R.D., Lambin, E.F., Naylor, R.L. (2013). Land institutions and supply chain configurations as determinants of soybean planted area and yields in Brazil. Land Use Policy, 31, 385-396. doi:10.1016/j.landusepol.2012.08.002

Ghanbari-Bonjar, A., Lee, H.C. (2003).Intercropped wheat (Triticum aestivum L.) and bean (Vicia faba L.) as whole-crop forage: effect of harvest time on forage yield and quality. Grass and Forage Science, 58, 28-36. doi:10.1046/j.13652494.2003.00348.x

Gong, C., ChangZhong, R., LaiChun, G., GuoJun, Z., YueGao, H., and ZhaoHai, Z. (2011). Effects of two spaces and intercropping on forage and crude protein yields of oat (Avena sativa L.) and common vetch (Vicia sativa L.). Acta Agronomica Sinica, 37(11), 2066-2074.

Han, C.C., Borman, C., Osantowski, D., Wagnitz, J., Koehler-Cole, K., Korus, K., Sonderegger, E., Werle, R., Wood, T., Lindquist, J.L. (2012). Productivity of field pea (Pisum sativum L.) and spring oat (Avena sativa L.) grown as sole and intercrops under different nitrogen levels. Journal of Agricultural Science, 4(11), 136-143.

Hauggaard-Nilsen, H., Ambus, P., Jensen, E.S. (2001). Interspecific competition, $\mathrm{N}$ use interference with weeds in pea-barley intercropping. Field Crop Research, 70, 101-109. doi:10.1016/S03784290(01)00126-5

Ijoyah, M.O., Fanen, F.T. (2012). Effects of different cropping pattern on performance of maize-soybean mixture in Makurdi, Nigeria. Scientific Journal of Crop Science, 1(2), 39-47.

Javanmard, A., Nasab, A.D.M., Javanshir, A., Moghaddam, M., Janmohammadi, H. (2009). Forage yield and quality in intercropping of maize with different legumes as double-cropped. Journal of Food, Agriculture and Environment, 7, 163-166.

Jensen, E.S. (1996).Grain yield, symbiotic $\mathrm{N}_{2}$ fixation and interspecific competition for inorganic $\mathrm{N}$ in pea-barley intercrops. Plant and Soil, 182, 25-38. doi:10.1007/BF00010992

Jing, Y., Chin, Y.J. (2013). Effects of twin-screw extrusion on soluble dietary fibre and physicochemical properties of soybean residue. Food Chemistry, 138, 884-889. doi:10.1016/j.foodchem.2012.12.003

Justino, G.C., Sodek, L. (2013).Recovery of nitrogen fixation after short-term flooding of the nodulated root system of soybean. Journal of Plant Physiology, 170, 235-241. doi:10.1016/j.jplph.2012.10.006

Karimuna, L., Leomo, S., Indriyani, L. (2012). Improvement of maize and peanut production in intercropping system through the application of organic fertilizer and mulch in ultisolsoil. Chiang Mai University of Natural Sciences, 11(1), 387-394.

Lauk, E., Lauk, R. (2005). The yields of legume-cereal mixed in years with high precipitation vegetation periods. Latvian Journal of Agronomy, 8, 281-285.

Lauk, R., Lauk, E. (2008). Pea-oat intercrops are superior to pea-wheat and pea-barley intercrops. Acta Agriculturae Scandinavica, Section B- Soil and Plant Science, 58, 139-144. doi:10.1080/09064710701412692

Lee, Y.J., Yoon, W.B. (2013). Effects of particle size and heating time on thiobarbituric acid (TBA) test of soybean powder. Food Chemistry, 138, 841-850. doi:10.1016/j.foodchem.2012.11.113

Li, Y., Ran, W., Li, X., Zhang, R., Sun, S., Xu, G. (2009). Facilitated legume nodulation, phosphate uptake and nitrogen transfer by arbuscular inoculation in an upland rice and mung intercropping system. Plant and Soil, 315, 285-296. doi:10.1007/s11104-008-9751-9

Lithourgidis, A.S., Vasilakoglou, I.B., Dhima, K.V., Dordas, C.A., Yiakoulaki, M.D. (2006). Forage yield and quality of common vetch mixtures with oat and triticale in two seedling ratios. Field Crops Research, 99, 106-113. doi:10.1016/j.fcr.2006.03.008

Malezieus, E., Crozat, Y., Dupraz, C., Laurans, M., Makowski, D., Ozier-Lafontaine, H.,Rapidel, B., DE Tourdonnet, S., Valantin-Morison, M. (2009). Mixing plant species in cropping systems: concepts, tools and models. A review. Agronomy for Sustainable Development, 29, 43-62. doi:10.1051/agro:2007057

Mariotti, M., Masoni, A., Ercoli, L., Arduini, I. (2009). Above-and below-ground competition between barley, wheat, lupin and vetch in a cereal and legume intercropping system. Grass and Forage Science, 64, 401-412. doi:10.1111/j.13652494.2009.00705.x

Mazza, C.A., Gimenez, P.I., Kantolic, A.G., Ballare, C.L. (2013). Beneficial effects of solar UV-B 
radiation on soybean yield mediated by reduced insect herbivory under field conditions. Physiologia Plantarum, 147, 307-315. doi:10.1111/j.13993054.2012.01661.x

Naumann, A., Heine, G., Rauber, R. (2010). Efficient discrimination of oat and pea roots by cluster analysis of fourier transform infrared (FTIR) spectra. Field Crops Research, 119, 78-84. doi:10.1016/j.fcr.2010.06.017

Pregl, F. (1945). Quantitative Organic Microanalysis. $4^{\text {th }}$ ed. J. A. Churchill Ltd. London, p. 126-129.

Sharma, S., Kaur, A., Bansal, A. (2013). Positional effects on soybean seed composition during storage. Journal of Food Science and Technology, 50(2), 353-359. doi:10.1007/s13197-011-0341-0
Soleymani, A., Shahrajabian, M.H.,Naranjani, L. (2011). The effects of nitrogen as starter fertilizer on ash percentage, important elements and solar radiation absorption of berseem clover cultivars intercropped by corn. Journal of Food, Agriculture and Environment, 9(1), 342-344.

Soleymani, A., Shahrajabian, M.H. (2012). Forage yield and quality in intercropping of forage corn with different cultivars of berseem clover in different levels of nitrogen fertilizer. Journal of Food, Agriculture and Environment, 10(1), 602-604.

Soleymani, A., Shahrajabian, M.H., Naranjani, L. (2012). Evaluation the benefits of different clover cultivars and forage corn intercropping in different levels of nitrogen fertilizer. Journal of Food, Agriculture and Environment, 10(1), 599-601. 